\title{
Statistical Reasoning Ability of Banda Aceh City High School Students
}

\author{
Vaniyon Ariwinanda ${ }^{1,}$ Cut M. Zubainur ${ }^{1, *}$ Hizir Sofyan ${ }^{2,}$ \\ ${ }^{1}$ Department of Mathematics Education, Syiah Kuala University, Indonesia \\ ${ }^{2}$ Statistics Department, Universitas Syiah Kuala \\ ${ }^{*}$ Corresponding author. Email: cut.morina@fkip.unsyiah.ac.id
}

\begin{abstract}
Statistical reasoning ability is the ability to understand the information that exists in everyday life based on statistical data, the ability to answer problems properly based on existing data in different ways, and obtain results that are not much different. The purpose of this study was to examine the statistical reasoning ability of high school students in Banda Aceh. This type of research is descriptive quantitative. The participants of this study were 64 students of five public senior high schools in Banda Aceh city. The data were collected by test. Analysis of the data which was used is descriptive statistics, the scores obtained by students will be converted into percentages. On average, the result showed that in the test on statistical reasoning ability, $65.91 \%$ of students still answered incorrectly, this shows that there are still many students misunderstandings in answering statistical questions. The low ability of students about statistical reasoning and the importance of this ability requires an effort from the teacher to improve students' statistical reasoning abilities.
\end{abstract}

Keywords: Statistical reasoning, Statistics education, SRA.

\section{INTRODUCTION}

Statistical reasoning is what students can do with statistical content and use their skills in using statistical concepts to solve statistical problems [1]. Statistical reasoning is a statistical way of thinking in producing statistical information [2]. This includes the ability to interpret a set of data, graphs, and a number of statistical information. Statistical reasoning contains some basic concepts regarding probability, variability, sample selection, data distribution, and normal distribution [1][3]. Therefore, the use of statistical reasoning is widely found in the world of education, especially in learning statistics [4].

Statistical skills are needed to be able to interpret and understand and make good decisions for statistical data, one of which is statistical reasoning [1][5]. Statistical reasoning is widely used in various circles of society [2], including 1. Psychology, which studies human behavior in assessing and making decisions based on statistical information; 2. Doctors and medical personnel, who need an understanding of the risks that can result from the health care carried out; 3 . Journalists and science writers, use it to convey statistical information well in various information media; 4. Political observers, use it in observing the course of elections and polls that occur. 5; Statistics teachers use it in teaching students to be able to do statistical calculations and understand statistical concepts and understand presenting data.

Once the knowledge of statistics and probability is so important, this material is one of the core materials in the 2013 Curriculum [6]. This is in line with the opinion of [7] that the purpose of learning statistics is that students understand statistics well so that they can obtain information from existing data, criticize, and make decisions based on that information, and aim to develop research skills. Strengthening and development of individual statistical reasoning as a result of schooling is needed [8].

Research on statistical reasoning ability has been conducted previously. An example of a research conducted by [9] with the aim of seeing how the statistical reasoning ability is based on the gender of students, the result is that there are differences in statistical reasoning abilities based on gender. Then there are [10] with a study to see the difference in statistical reasoning ability between elementary and junior high school mathematics teacher candidates, [11] with the aim of the study looking at the difference in statistical 
reasoning ability between high school students in China and the Netherlands. [12] with the aim of looking at the statistical reasoning ability of junior high school students, the result is that the statistical reasoning of junior high school students is still low. Furthermore, there is [13] with the aim of researching the statistical reasoning ability of junior and senior high school teachers, the result is that the statistical reasoning ability of junior and senior high school teachers is in a good category.

There are still little researches on the statistical reasoning ability of Banda Aceh High School students and the importance of this ability, so it is necessary to look at the statistical reasoning abilities of Banda Aceh City High School students. This study aims to examine the statistical reasoning ability of high school students in Banda Aceh. The results of this study can be new information about the statistical reasoning abilities of students in the city of Banda Aceh so that policies or actions can be taken for statistical learning in the future.

\section{METHODS}

This study aims to measure the statistical reasoning ability of high school students in Banda Aceh. The type of research conducted is descriptive quantitative. According to [14], descriptive quantitative is a type of research used to analyze data by describing or describing the data that has been collected as it is. In this study, the data obtained were analyzed to describe or describe the statistical reasoning ability of high school students in Banda Aceh. The research design used is a survey research design. Survey research is a procedure in quantitative research in which research administers attitudes, opinions, behaviors, or specific characteristics of a population [15]. The participants of this study were 64 students of public senior high schools in Banda Aceh city.

The instrument used in this article is the Statistical Reasoning Assessment (SRA) developed by [1]. This instrument is also used by [10] in their journal entitled Prospective elementary and secondary school mathematics teachers' statistical reasoning. This instrument aims to see the statistical reasoning ability of students in analyzing and interpreting data and using statistical information in everyday life. This instrument basically uses English and is then translated into Indonesian with the help of a linguist, then the Indonesian language instrument obtained is translated back into English with the help of a linguist. Finally, the final instrument in Indonesian was obtained which was equivalent to the original instrument.
Table 1. Statistical reasoning test questions

\begin{tabular}{|c|l|c|}
\hline No & Measured Reasoning Skills & Question Form \\
\hline 1 & $\begin{array}{l}\text { Understand how to choose } \\
\text { the appropriate average }\end{array}$ & $\begin{array}{c}\text { Multiple } \\
\text { choice }\end{array}$ \\
\hline 2 & $\begin{array}{l}\text { Understanding probability as } \\
\text { a ratio }\end{array}$ & $\begin{array}{c}\text { Multiple } \\
\text { choice }\end{array}$ \\
\hline 3 & $\begin{array}{l}\text { Understanding sampling } \\
\text { variability }\end{array}$ & $\begin{array}{c}\text { Multiple } \\
\text { choice }\end{array}$ \\
\hline 4 & $\begin{array}{l}\text { Interpret probability } \\
\text { correctly }\end{array}$ & $\begin{array}{c}\text { Multiple } \\
\text { choice }\end{array}$ \\
\hline 5 & $\begin{array}{l}\text { Distinguish between } \\
\text { correlation and causation }\end{array}$ & $\begin{array}{c}\text { Multiple } \\
\text { choice }\end{array}$ \\
\hline 6 & Understanding independence & $\begin{array}{c}\text { Multiple } \\
\text { choice }\end{array}$ \\
\hline
\end{tabular}

Source: [1]

Quantitative data collection techniques were done by tests. The test is a psychological research method to obtain information about various aspects of a person's behavior and inner life, using measurements that produce a quantitative description of the aspects studied [15].

Analysis of the data used is descriptive statistics, statistics used to analyze the data by describing the data collected [16]. In addition, the scores obtained by students will be calculated on average and then converted into percentages, so that it can be concluded how the statistical abilities of high school students in Banda Aceh city are.

\section{RESULTS AND DISCUSSION}

The results of data processing of high school students reasoning abilities in Banda Aceh are presented in Table 2 below.

Table 2. The results of data on statistical reasoning abilities of high school students in Banda Aceh city

\begin{tabular}{|c|l|c|c|}
\hline No & \multicolumn{1}{|c|}{$\begin{array}{c}\text { Measured Reasoning } \\
\text { Skills }\end{array}$} & $\begin{array}{c}(\%) \\
\text { Correct } \\
\text { answer }\end{array}$ & $\begin{array}{c}\text { Wrong } \\
\text { answer }\end{array}$ \\
\hline 1 & $\begin{array}{l}\text { Understand how to } \\
\text { choose the appropriate } \\
\text { average }\end{array}$ & $7.8 \%$ & $92.2 \%$ \\
\hline 2 & $\begin{array}{l}\text { Understanding } \\
\text { probability as a ratio }\end{array}$ & $62.5 \%$ & $37.5 \%$ \\
\hline 3 & $\begin{array}{l}\text { Understanding } \\
\text { sampling variability }\end{array}$ & $28.1 \%$ & $71.9 \%$ \\
\hline 4 & $\begin{array}{l}\text { Interpret probability } \\
\text { correctly }\end{array}$ & $54.6 \%$ & $45.4 \%$ \\
\hline 5 & $\begin{array}{l}\text { Distinguish between } \\
\text { correlation and } \\
\text { causation }\end{array}$ & $12.5 \%$ & $87.5 \%$ \\
\hline 6 & $\begin{array}{l}\text { Understanding } \\
\text { independence }\end{array}$ & $39 \%$ & $61 \%$ \\
\hline & & & \\
\hline
\end{tabular}

There are 6 statistical skills measured in this study. Skills about understanding how to choose the appropriate average (Figure 1), 7.8\% of students answered correctly and $92.2 \%$ of students who answered incorrectly. This 
shows that there are still many misunderstandings involving the average. $68.7 \%$ of students answered option A, where the error was to assume the average was the most common number or the most frequently occurring number, to find the average one must always add up all the numbers and divide by the number of data values. $15.6 \%$ of students answered option $\mathrm{C}$, where the error was failing to consider outliers when calculating the average. Option D is the most appropriate answer because you have to discard data that deviate very far from the other data and then calculate the average to get the most accurate answer.

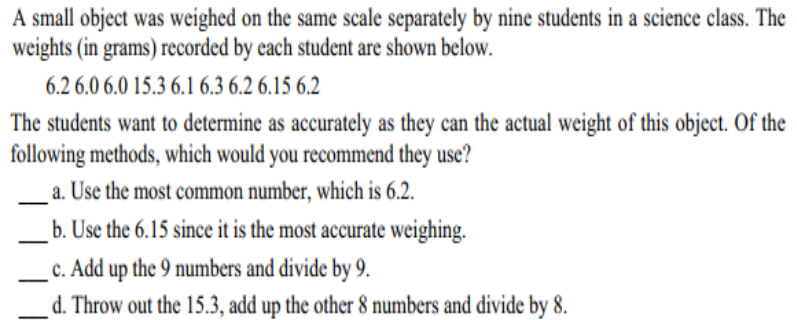

\section{Figure 1 Question number 1}

Skills about understanding probability as a ratio (Figure 2), 62.5\% of students answered correctly, and $37.5 \%$ of students answered incorrectly. The number of students who answered correctly on this question could be an indication that students understand probability as a ratio, where container $\mathrm{A}$ and container $\mathrm{B}$ have the same chance of getting a blue marble, which is $40 / 100$ or $4 / 10$.

Two containers, labeled $\underline{\mathrm{A}}$ and $\underline{\mathrm{B}}$, are filled with red and blue marbles in the following quantities:
\begin{tabular}{ccc} 
Container & Red & Blue \\
\hline A & 6 & 4 \\
B & 60 & 40 \\
\hline
\end{tabular}

Each container is shaken vigorously. After choosing one of the containers, you will reach in and, without looking, draw out a marble. If the marble is blue, you win $\$ 50$. Which container gives you the best chance of drawing a blue marble?

a. Container A (with 6 red and 4 blue)

b. Container B (with 60 red and 40 blue

c. Equal chances from each container

Figure 2 Question number 2.

Skills about understanding sampling variability (Figure 3), 28.1\% of students answered correctly, and $71.9 \%$ of students answered incorrectly. This question has three options, the number of students who answered correctly can be an indication that students understand sampling variability. $46.8 \%$ of students who answered option $\mathrm{C}$, the error was in the Law of small numbers, namely assuming that a small sample resembles the population from which they were sampled so that a small sample is used as a basis for inference and generalization. Option B is the most appropriate answer because with half male and half female births and the average total births at hospitals $\mathrm{A}$ and $\mathrm{B}$ are 60 , the average birth is 30 male and 30 female. Only hospital B (with 10 births a day) is eligible to record $80 \%$ or more female births.
Half of all newborns are girls and half are boys. Hospital A records an average of 50 births a day. Hospital B records an average of 10 births a day. On a particular day, which hospital is more likely to record $80 \%$ or more female births?

a. Hospital $\mathrm{A}$ (with 50 births a day)

b. Hospital B (with 10 births a day)

_c. The two hospitals are equally likely to record such an event.

Figure 3 Question number 3.

Skills about interpreting probability correctly (Figure 4), $54.6 \%$ of students answered correctly, and $45.4 \%$ of students answered incorrectly. $6.25 \%$ of students who answered option E, had a misunderstanding about outcome orientation, namely ignoring the fact that any event might occur, meaning that the rash event could happen. Option D is the most appropriate answer because, with a $15 \%$ chance of getting a rash, about 15 people out of a hundred people will experience a rash if they take the drug or $15 / 100=15 \%$

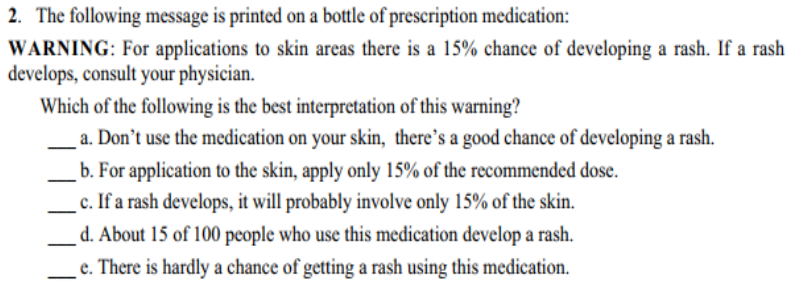

Figure 4 Question number 4.

Skills about distinguishing between correlation and causation (Figure 5), 12.5\% of students answered correctly, and $87.5 \%$ of students answered incorrectly. Students who answered options A and option D had a misconception that a good sample could represent a high percentage of the population, meaning that 500 people could be a good sample and could represent the population and that one month could represent the estimated time students watched television. Students who answered option B and option E had an error that there was no causal correlation in that option, meaning that there was no relationship between the answers given and the information about the questions. Option $\mathrm{C}$ is the most appropriate answer because it is in accordance with the information given to the question.

\footnotetext{
For one month, 500 elementary students kept a daily record of the hours they spent watching television. The average number of hours per week spent watching television was 28 . The researchers conducting the study also obtained report cards for each of the students. They found that the students who did well in school spent less time watching television than those students who did poorly. Listed below are several possible statements concerning the results of this research. Place a check by every statement that you agree with.

_a. The sample of 500 is too small to permit drawing conclusion.

b. If a student decreased the amount of time spent watching television, his or her performance in school would improve.

c. Even though students who did well watched less television, this doesn't necessarily mean that watching television hurts school performance.

d. One month is not a long enough period of time to estimate how many hours the student really spend watching television.

e. The research demonstrates that watching television causes poorer performance in school. f $\mathrm{f}$. I don't agree with any of these statements.
}

\section{Figure 5 Question number 5}

Skills about understanding independence (Figure 6), $39 \%$ of students answered correctly, and $61 \%$ of students answered incorrectly. Option E became the correct 
answer, students who answered other than option $\mathrm{E}$ had a misunderstanding about representativeness. Because tossing a coin with 2 sides (numbers and pictures) has the same chance of being tossed.

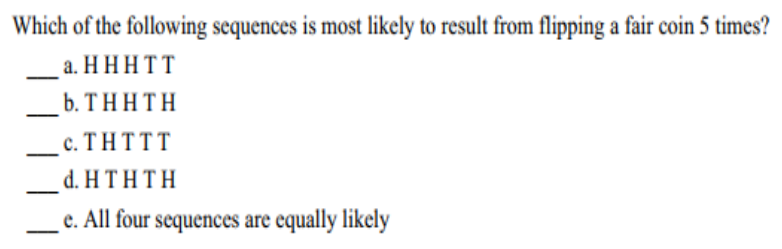

Figure 6 Question number 6.

The results of this study indicate that the statistical reasoning ability test given to students in the city of Banda Aceh, on average $65.91 \%$ of students still answered incorrectly. This is in line with [17] research which investigated students' reasoning abilities where only $29 \%$ of Indonesian students were able to solve problems about data and probability. [18] research on statistical reasoning shows that only $29.52 \%$ of high school students in Palembang understand data representation. The results of the study on the statistical reasoning ability of senior high schools in Banda Aceh showed that students still did not understand the statistical material well. This shows that the statistical reasoning ability of Banda Aceh city students is still relatively low. This number is very small so there is a need for innovation so that students better understand statistics material.

\section{CONCLUSION}

Statistical reasoning is widely used in various circles of society such as psychologists, doctors, and medical personnel, journalists and science writers, political observers, etc. This ability should be owned by every student considering its importance and usefulness in the world of work. Based on the results of research on statistical reasoning abilities, $92.2 \%$ of students misunderstood how to choose the appropriate average, $37.5 \%$ of students misunderstood probability as a ratio, $71.9 \%$ of students misunderstood sampling variability, $45.6 \%$ of students misinterpreted probability by correct, $87.5 \%$ of students misunderstood correlation and causation and $61 \%$ of students misunderstood independence. On average, on the test on statistical reasoning ability, $65.91 \%$ of students still answered incorrectly, this shows that there are still many students' misunderstandings in answering statistics questions. The low ability of high school students in Banda Aceh in terms of statistical reasoning and the importance of this ability requires efforts from teachers to improve students' statistical reasoning abilities. This study provides an overview of the statistical ability of high school students in Banda Aceh by giving a Statistical Reasoning Assessment (SRA) test with a total of 6 questions and 6 statistical reasoning skills being measured, of course, there are still many statistical reasoning skills that can be measured for future research. Interviews can be conducted to ascertain whether students really understand in answering test questions or are just guessing, the large number of samples makes researchers not conduct in-depth interviews.

\section{AUTHORS' CONTRIBUTIONS}

All authors conceived and designed this study. All authors contributed to the process of revising the manuscript, and at the end, all authors have approved the final version of this manuscript.

\section{REFERENCES}

[1] J. Garfield, The challenge of developing statistical reasoning, Journal of Statistics Education 10(3) (2002).

DOI: https://doi.org/10.1080/10691898.2002.11910676

[2] R.C. DelMas, Statistical literacy, reasoning, and thinking: A commentary, Journal of Statistics Education 10(2) (2002). DOI: https://doi.org/10.1080/10691898.2002.11910674

[3] J. Watson and R. Callingham, Statistical literacy: A complex hierarchical construct Statistics, Education Research Journal 2(2) (2003) 3-46. URL: http://iaseweb.org/documents/SERJ/SERJ2(2)_Watson_Calli ngham.pdf

[4] T. Coladarci T, C.D Cobb, E.W Minium and R.C Clarke, Fundamentals of statistical reasoning in education. John Wiley \& Sons (2010). URL: https://books.google.com/books?hl=en\&lr=\&id=du e + H9uyOaUC\&oi=fnd\&pg $=$ PA1\&dq $=$ T. + Coladarc i+T,+C.D+Cobb,+E.W+Minium+and+R.C+Clarke, + Fundamentals+of+statistical+reasoning+in+educa tion.+John+Wiley+\%26+Sons+(2010)\&ots=p5Lky kGcYn\&sig=RB29oLUIzV2DhftCAs3gg_FTFZM

[5] Y. Yusuf, Analisis Kemampuan Penalaran Ukuran Statistika dengan Menggunakan Model Pembelajaran Berbantuan Program R (PSB-R), JESA-Jurnal Edukasi Sebelas April 1(1) (2017) 2232.

URL:

https://ejournal.stkip11april.ac.id/index.php/jesa/art icle/view/61

[6] M. Hafiyusholeh, Literasi statistik dan urgensinya bagi siswa, Wahana: Tridharma Perguruan Tinggi 64(1) (2015) 1-8. URL: http://jurnal.unipasby.ac.id/index.php/whn/article/v iew/531

[7] D.J Rumsey, Statistics for dummies, John Wiley \& Sons (2016).

URL:

https://books.google.com/books?hl=en\&lr=\&id=eC DNDQAAQBAJ\&oi=fnd\&pg $=$ PT7 $\& d q=D . J+R u m$ 
$\underline{\text { sey, }+ \text { Statistics+for+dummies, }+ \text { John+Wiley }+\% 26+}$ $\underline{\text { Sons+(2016)\&ots=ZW0fpSjgMP\&sig=YqamYlP8 }}$ WEfbuJVNhryukUzfwVU

[8] I. Gal, Adults' statistical literacy: Meanings, components, responsibilities, International statistical review 70(1) (2002) 1-25. DOI: https://doi.org/10.1111/j.17515823.2002.tb00336.x

[9] N. Martin, J. Hughes, and J. Fugelsang, The Roles of Experience, Gender, and Individual Differences in Statistical Reasoning, Statistics Education Research Journal 16(2) (2017). URL: https://iaseweb.org/documents/SERJ/SERJ16(2)_Martin.pdf

[10] R. Karatoprak, G.K Akar and B. Börkan, Prospective elementary and secondary school mathematics teachers' statistical reasoning, International Electronic Journal of Elementary Education (2) (2015) 107-124. URL: https://www.iejee.com/index.php/IEJEE/article/vie $\mathrm{w} / 69$

[11] W. Wang, X Wang, and G Chen, Survey and analysis of the statistical reasoning among high school students in China and Dutch, Journal of Mathematics Education 2(1) (2009) 15-26. URL: http://www.educationforatoz.org/images/_2 Wenfa ng Wang_Final.pdf

[12] I. Maryati and N. Priatna, Analisis Kesulitan dalam Materi Statistika Ditinjau dari Kemampuan Penalaran dan Komunikasi Statistis, Prisma 6(2) (2017) 173-179.

URL: https://jurnal.unsur.ac.id/prisma/article/view/209

[13] B.A.P Martadiputra 2010 Kajian Tentang Kemampuan Melek Statistis Statistical Literacy, Penalaran Statistis Statistical Reasoning, Dan Berpikir Statistis Statistical Thinking Guru Smp, Saung-Guru 83 (2010). URL: http://jurnal.upi.edu/saung-guru/view/399/kajiantentang-kemampuan-melek-statistis-(statisticalliteracy),-penalaran-statistis-(statistical-reasoning),dan-berpikir-statistis-(statistical-thinking)-guru$\underline{\mathrm{smp}}$
[14] Sugiyono, Metode Penelitian Kuantitatif, Kualitatif dan R\&D, Bandung Alfabeta, 2015

[15] J.W Creswell, Research Design: Qualitative, Quantitative, and Mixed Methods Approaches, Sage Publications, 2017

[16] H. Sofyan, R. Rasudin, M. Miftahuddin, K. Saputra, M. Marzuki, M. Iqbal, and D. Maulana, Analisis Kepuasan Pengguna Aplikasi RWikiStat 3.0, Journal of Data Analysis 2(2) (2020) 80-87. DOI: https://doi.org/10.24815/jda.v2i2.16104

[17] R. Rosnawati, Kemampuan penalaran matematika siswa SMP Indonesia pada TIMSS 2011, Prosiding Seminar Nasional Penelitian, Pendidikan dan Penerapan MIPA, Fakultas MIPA, Universitas Negeri Yogyakarta (8) (2013) 1-6. URL: http://staffnew.uny.ac.id/upload/132001808/penelit ian/Makalah+Semnas+2013+an+R+Rosnawati+F MIPA+UNY.pdf

[18] S. Nisa, Z Zulkardi and E Susanti, Kemampuan penalaran statistis siswa pada materi penyajian data histogram melalui pembelajaran PMRI, Jurnal Pendidikan Matematika 13(1) (2019) 21-40. URL: https://core.ac.uk/download/pdf/267822182.pdf 